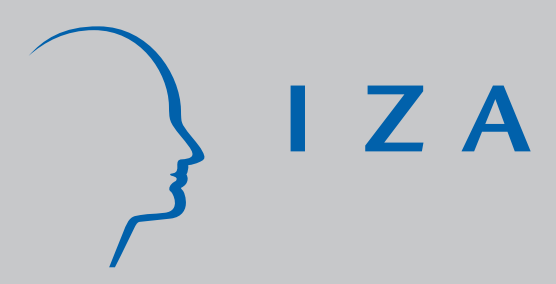

IZA DP No. 5893

Immigration and House Prices in the UK

Filipa Sá

July 2011

Forschungsinstitut zur Zukunft der Arbeit Institute for the Study of Labor 


\title{
Immigration and House Prices in the UK
}

\author{
Filipa Sá \\ Trinity College, University of Cambridge \\ and IZA
}

Discussion Paper No. 5893

July 2011

IZA

P.O. Box 7240

53072 Bonn

Germany

Phone: +49-228-3894-0

Fax: +49-228-3894-180

E-mail: iza@iza.org

Any opinions expressed here are those of the author(s) and not those of IZA. Research published in this series may include views on policy, but the institute itself takes no institutional policy positions.

The Institute for the Study of Labor (IZA) in Bonn is a local and virtual international research center and a place of communication between science, politics and business. IZA is an independent nonprofit organization supported by Deutsche Post Foundation. The center is associated with the University of Bonn and offers a stimulating research environment through its international network, workshops and conferences, data service, project support, research visits and doctoral program. IZA engages in (i) original and internationally competitive research in all fields of labor economics, (ii) development of policy concepts, and (iii) dissemination of research results and concepts to the interested public.

IZA Discussion Papers often represent preliminary work and are circulated to encourage discussion. Citation of such a paper should account for its provisional character. A revised version may be available directly from the author. 
IZA Discussion Paper No. 5893

July 2011

\section{ABSTRACT}

\section{Immigration and House Prices in the UK}

This article studies the effect of immigration on house prices in the UK. It finds that immigration has a negative effect on house prices and presents evidence that this negative effect is due to the mobility response of the native population. Natives respond to immigration by moving to different areas and those who leave are at the top of the wage distribution. This generates a negative income effect on housing demand and pushes down house prices. The negative effect of immigration on house prices is driven by local areas where immigrants have lower education.

JEL Classification: J61, R21

Keywords: immigration, house prices

Corresponding author:

Filipa Sá

Trinity College

University of Cambridge

Trinity Street

CB2 1 TQ Cambridge

United Kingdom

E-mail: fgs22@cam.ac.uk

* The special license access version of the LFS used in this article was made available by the UK Data Archive and was originally collected by the ONS. 


\section{Introduction}

The UK has experienced a steady increase in immigration in recent years. Until the mid-1990s immigrants accounted for less than $8 \%$ of the working age population in the UK. Today they account for more than $12 \%$ (Figure 1$)^{1}$. There is considerable heterogeneity in the geographic distribution of immigrants. Table 1 lists the local authorities with the largest share of immigrants in the working age population in 2010. Not surprisingly, this share is largest in some London boroughs where immigrants account for the majority of the population. Outside London, there are several local authorities where over $20 \%$ of the population is foreign born. These large immigration flows could have significant effects on the economies of the areas where immigrants cluster. This is the subject of an intense political debate - see, for example, House of Lords report (2008) — and was one of the dominant issues in the 2010 election.

There is a large literature looking at the labour market impact of immigration ${ }^{2}$. The general conclusion is that immigration has only small adverse effects on employment and wages. For the UK this result is confirmed by Dustmann, Fabbri and Preston (2005), who find no strong evidence that immigration has overall effects on employment, participation and wages. This article takes a different perspective and looks at the effect of immigration on the housing market. It follows the dominant methodology in the literature and uses spatial correlations between immigrant inflows and changes in house prices in different geographic areas. To avoid the possible endogeneity resulting from the fact that immigrant inflows are themselves the outcome of economic decisions, an instrumental variable based on the settlement pattern of immigrants in an earlier period is used. This identification strategy is based on the tendency of newly arriving immigrants to settle in places where previous immigrants from the same country already live.

The sign and magnitude of the effect of immigration on house prices is theoretically ambiguous. In principle, immigrant inflows would increase the demand for housing. Combined with an upward-sloping housing supply, this would lead to an increase in house prices and rents. However, immigration may be associated with offsetting native out-migration. If the offset is complete, local population would remain constant. In this case housing demand may still be affected if the change in composition of the local population leads to a change in local income. This would affect housing demand and house prices and rents via an income effect.

Studies of the impact of immigration on house prices and rents generally find a positive effect. Saiz (2007) looks at house prices and rents across cities in the US. He finds that an immigration inflow equal to $1 \%$ of a city's population is associated with an increase in average rents of about $1 \%$ and an increase in average prices of 2.9 to $3.4 \%$. For Switzerland, Degen and Fischer (2009) find that an immigration inflow equal to $1 \%$ of an area's population increases prices of single family homes by about 2.7\%. For Spain, Gonzalez and Ortega (2009) find a coefficient of $3.2 \%$ for house prices. In contrast to these studies, Akbari and Aydede (2009) and Stillman and Maré (2008) find

\footnotetext{
${ }^{1}$ The definition of immigrants adopted in this article is based on country of birth.

${ }^{2}$ See Dustmann and Glitz (2005) for a survey of this literature.
} 
that immigration has only small effects on house prices in Canada and New Zealand. These two studies use Census data and thus examine long-run effects. Because housing supply is likely to be more elastic in the long-run, it is not surprising that immigration would have a smaller impact on house prices and rents between Census dates than between consecutive years.

This article studies the effect of immigration on house prices in the UK. It is the first to study the effects of immigration in the UK using data disaggregated by local authority. Previous studies work with a broader classification of regions to match government office regions. This is the only level of disaggregation possible with the standard publicly-available version of the UK Labour Force Survey (LFS). The immigration data used in this article are from the special license access version of the UK LFS, obtained via an agreement with the Office of National Statistics (ONS). The final data set used in the estimations covers 159 local authorities in England and Wales, including all 32 London boroughs, in the period from 2003 to 2010.

In contrast to what has been found for other countries, my results suggest that immigration has a negative effect on house prices at the local level. Specifically, an immigration inflow equal to $1 \%$ of the local initial population leads to a reduction of $1.6 \%$ in house prices. To explore the channels through which this effect is likely to take place, I look at the effect of immigration on native population growth and mobility and find that immigration leads to native outflows. I then look at how this change in the composition of the local population affects the local wage distribution. I find a positive correlation between immigration and the fraction of the local population in the first quartile of the wage distribution. This is mostly due to the fact that the native population tends to have lower wages in high immigration cities. Two factors are behind this result. First, there is some evidence that immigration reduces native wages at the lower end of the wage distribution. Second, natives who move to a different local authority tend to be at the higher end of the wage distribution.

To study whether the effect of immigration on house prices depends on the characteristics of the local immigrant population, I divide local authorities into four groups according to the level of education of the immigrant population. I find that the negative effect of immigration on house prices is driven by local authorities where immigrants have lower education. This is consistent with immigration having a positive income effect on housing demand in regions where immigrants have higher education (and higher wages), counteracting the negative income effect generated by native out-mobility.

The final section of this article looks at results with more aggregated regions. To match previous studies, I divide England and Wales into ten government office regions and repeat the analysis of the effects of immigration on house prices using this definition of local market. The estimates are more imprecise because the sample is smaller and show no evidence that immigration has any effect on house prices once regions are aggregated to this level. This is consistent with the analysis in Borjas (2006) and suggests that native mobility may diffuse the effects of immigration throughout these broad regions. Immigration may have important economic effects at the local level which are only captured when the labour market is defined at a sufficiently disaggregated level. 
The rest of the paper is organized as follows. Section 2 presents a model that studies the effect of immigration on house prices. The model allows for mobility by natives and includes an income effect on the demand for housing. Section 3 discusses the empirical methodology. Section 4 describe the data and descriptive statistics. Empirical results are reported and discussed in Section 5. Section 6 reports results with more aggregated regions and Section 7 presents conclusions.

\section{The Model}

A simple model is introduced to illustrate the link between immigration, native mobility and house prices. It follows closely the model in Saiz (2007) and extends it to include income effects in housing consumption and the preference of natives for immigration. The model focuses on the effects of immigration on a given city $C$.

There are two types of workers in the city: natives $(N)$ and immigrants $(I)$. While immigrants are homogeneous, natives are heterogeneous both in wages and in their preference for local amenities. We assume that there are two types of natives in the city: high income natives $\left(N^{H}\right)$ and low income natives $\left(N^{L}\right)$. Due to mobility costs only high income natives can move from city $C$ to an another city. Low income natives cannot move and their supply is treated as exogenous.

The preferences of high income native resident $i$ is given by:

$$
U_{i C}=V_{i C}+h^{\frac{1}{2}} \cdot x^{\frac{1}{2}}-\delta \cdot I
$$

$V_{i C}$ is the value of the local amenities of city $C$ for native $i$. The second term is a CobbDouglas utility function on consumption of housing services $(h)$ and consumption of other goods $(x)$. The last term captures the preference of natives for immigration. If natives have a distaste for immigration the coefficient $\delta$ is positive. If natives like to live in cities with high immigration

- for example, because they value cultural diversity - the coefficient $\delta$ is negative.

Individuals maximize utility subject to the following budget constraint:

$$
R \cdot h+x=W^{H}
$$

where $R$ denotes housing rents and $W^{H}$ is the wage of high income native workers. The price of other goods $x$ has been normalized to one.

The utility maximization problem delivers the following demand functions for housing and other goods:

$$
\begin{aligned}
h & =\frac{1}{2} \cdot \frac{W^{H}}{R} \\
x & =\frac{1}{2} \cdot W^{H}
\end{aligned}
$$

Following Saiz (2007), I order high income natives according to their preference for local ameni- 
ties, $i \in\{1,2, \ldots, N\}$, and assume that the preferences for each individual are given by $V_{i C}=A-a \cdot i$.

Wages of high and low income natives are allowed to depend on the number of immigrants in the city according to a linear function $W^{H}=\bar{W}^{H}-\rho_{H} \cdot I$ and $W^{L}=\bar{W}^{L}-\rho_{L} \cdot I$. No restrictions are imposed on the sign of $\rho_{H}$ and $\rho_{L}$. If immigrants are substitutes to native workers, then $\rho$ would be positive and immigration would depress the wage of natives. On the other hand, if immigrants are complements to native workers, $\rho$ would be negative and immigration would have a positive effect on the wage of natives. This captures the mechanism described in Ottaviano and Peri (2007), where immigration has a positive effect on the wages of highly educated natives due to complementarities in production and has a negative effect on the wages of less educated natives due to substitution in production. In our model this would imply $\rho_{H}<0$ and $\rho_{L}>0$. To simplify the analysis, we do not consider complementarity or substitutability among native workers.

To model the mobility decision of high income natives, assume that the utility level that can be attained outside the city is $\bar{U}$. Native resident $i$ decides to stay in the city if $U_{i C} \geqslant \bar{U}$. The marginal native is indifferent between staying and leaving. Substituting the demand functions (2) into the utility function (1) gives the following indifference condition for the marginal native $N^{H}$ :

$$
A-a \cdot N^{H}+\frac{1}{2} \cdot W^{H} \cdot R^{-\frac{1}{2}}-\delta \cdot I=\bar{U}
$$

This condition determines the number of high income native residents in the city:

$$
N^{H}=\frac{1}{a}\left[A-\bar{U}+\frac{1}{2} \cdot W^{H} \cdot R^{-\frac{1}{2}}-\delta \cdot I\right]
$$

The supply of immigrants $I$ is treated as exogenous and immigrants are assumed to always prefer to stay in city $C$. We further assume that the demand of housing services by low income natives and by immigrants is identical to that of high income natives. Immigrants are homogeneous and have wage $\overline{W_{I}}$.

The total demand for housing services equals the sum of the demand by natives and by immigrants:

$$
H^{D}=\frac{1}{2} \cdot \frac{1}{R}\left[N^{H} \cdot W^{H}+N^{L} \cdot W^{L}+I \cdot \bar{W}_{I}\right]
$$

The term in square brackets is total wealth in the city. Taking logs of this equation:

$$
\ln H^{D}=-\ln 2-\ln R+\ln \text { Wealth }
$$

The response of housing costs to immigration and native mobility depends on the elasticity of supply. In areas where housing supply is more elastic, housing costs should increase by less in response to an increase in demand. The link between house prices and supply elasticity is studied in Glaeser, Gyourko and Saiz (2008). Their model predicts that places with more elastic housing supply have fewer and shorter housing bubbles, with smaller price increases. This prediction is supported by data for US metropolitan areas. Favara and Imbs (2010) study the effect of branching 
deregulation in the US in 1994. Deregulation relaxes access to mortgage credit and increases demand for house ownership. Their evidence suggests that house prices rise with branching deregulation, particularly in metropolitan areas where construction is inelastic for topographic reasons.

To capture the effect of the elasticity of housing supply on the response of housing costs to immigration and native mobility, I follow Saiz (2007) and adopt the following specification for housing supply:

$$
\ln H^{S}=\beta_{0}+\beta_{1} \ln P
$$

where $\beta_{1}$ is the price elasticity of housing supply and $P$ is the price of housing, which equals the present value of housing rents discounted at rate $d: P=\frac{R}{d}$ or $\ln P=\ln R-\ln d$.

In equilibrium housing demand equals supply. Combining equations (4) and (5) gives:

$$
\ln P=\frac{1}{1+\beta_{1}} \cdot\left[-\ln 2-\ln d-\beta_{0}+\ln \text { Wealth }\right]
$$

We are interested in the effect of immigration on house prices $\frac{d P}{d I}$. From the equation (6), we have:

$$
\frac{d P}{d I}=P \cdot \frac{1}{1+\beta_{1}} \cdot \frac{1}{W e a l t h} \cdot \frac{d W e a l t h}{d I}
$$

Using the definition of wealth we obtain:

$$
\frac{d W e a l t h}{d I}=\frac{d N^{H}}{d I} \cdot W^{H}-N^{H} \cdot \rho_{H}-N^{L} \cdot \rho_{L}+\bar{W}_{I}
$$

If immigrant inflows are completely offset by native outflows $\left(\frac{d N^{H}}{d I}=-1\right)$, there may still be an effect on wealth and house prices even if native wages are not affected (i.e., $\rho_{H}=\rho_{L}=0$ ). This happens if the wages of natives who leave are different from the wages of immigrants who come into the city (i.e., $W^{H} \neq \bar{W}_{I}$ ). In this case, the level of wealth in the city will change and house prices will be affected via the income effect.

It can also be seen that, even if immigration has no impact on the mobility decisions of natives $\left(\frac{d N^{H}}{d I}=0\right)$, it can still have an effect on house prices. This effect is unambiguously positive if immigration has no effect on native wages $\left(\rho_{H}=\rho_{L}=0\right)$. Otherwise, the sign of the effect depends on how immigrant wages compare with the change in native wages.

The mobility response of natives to immigration $\left(\frac{d N^{H}}{d I}\right)$ can be derived from equation (3):

$$
\frac{d N^{H}}{d I}=-\frac{1}{a} \cdot\left[\frac{1}{2} \cdot \rho_{H} \cdot(P \cdot d)^{-\frac{1}{2}}+\frac{1}{4} \cdot W^{H} \cdot(P \cdot d)^{-\frac{3}{2}} \cdot d \cdot \frac{d P}{d I}+\delta\right]
$$

Natives respond to immigration by moving out of the city if immigration has a negative effect on native wages (positive $\rho_{H}$ ), if it has a positive effect on house prices (positive $\frac{d P}{d I}$ ) and if natives have a distaste for immigration (positive $\delta$ ).

Combining equations (7), (8) and (9) gives: 


$$
\frac{d P}{d I}=-\frac{P \cdot\left[\frac{1}{a} \cdot\left[\frac{1}{2} \cdot \rho_{H} \cdot(P \cdot d)^{-\frac{1}{2}}+\delta\right] \cdot W^{H}+N^{H} \cdot \rho_{H}+N^{L} \cdot \rho_{L}-\bar{W}_{I}\right]}{\left(1+\beta_{1}\right) \cdot \text { Wealth }+\frac{1}{a} \cdot \frac{1}{4} \cdot W^{H} \cdot(P \cdot d)^{-\frac{1}{2}}}
$$

The sign of the effect of immigration on house prices is ambiguous. The effect will tend to be negative if immigration leads to a reduction in native wages $\left(\rho_{H}>0\right.$ and $\left.\rho_{L}>0\right)$ and if natives dislike immigration $(\delta>0)$. In this case, high income natives will leave the city and house prices will be depressed. On the other hand, the effect will tend to be positive if complementarities in production lead to a positive effect of immigration on native wages $\left(\rho_{H}<0\right.$ and $\left.\rho_{L}<0\right)$, if natives have a positive preference for immigration $(\delta<0)$ or if the wage of immigrants is large.

This result contrasts with Saiz (2007), where immigration has an unambiguously positive effect on house prices. There are two differences between his model and the one used here. First, I introduce a parameter that captures the preference of natives for immigration $(\delta)$. If this parameter is large and positive, natives dislike immigration. In this case, more natives will leave the city in response to immigration and house prices will decrease as a result. In addition, I extend the model in Saiz (2007) to introduce income effects in the demand for housing. This amplifies the negative effect of native out-migration on house prices, especially if natives who leave the city are the ones with higher income.

This equation also shows that the response of house prices to immigration is smaller in cities

where supply is more elastic, i.e. $\frac{\partial\left|\frac{d P}{d I}\right|}{\partial \beta_{1}}<0$. This is intuitive and consistent with the findings in Glaeser, Gyourko and Saiz (2008) and Favara and Imbs (2010). If housing supply is more elastic, it will respond to demand conditions: an increase in demand will lead to more housing construction and a smaller increase in house prices, while a reduction in demand will lead to less construction and a smaller reduction in prices.

With this theoretical framework in mind, I now turn to the empirical evidence. I first look at the effect of immigration on house prices and then explore the channels that the model indicates to be important in determining this effect. In particular, I study the effect of immigration on native mobility and wages.

\section{Methodology}

The following model is used to estimate the effect of immigration on house prices:

$$
\Delta \ln \left(P_{i t}\right)=\beta \frac{\Delta F B_{i t}}{P_{o p} i t-1}+\gamma X_{i t}+\phi_{t}+\rho_{i}+\varepsilon_{i t}
$$

where $\Delta \ln \left(P_{i t}\right)$ is the change in the log of the house price index in local authority $i$ between years $t-1$ and $t$. The main independent variable is the annual inflow of immigrants divided by the initial population. The coefficient $\beta$ can be interpreted as the percentage change in house prices corresponding to an annual inflow of immigrants equal to $1 \%$ of the local initial population. $X_{i t}$ is 
the change in employment to population ratio at the local level, which controls for macroeconomic conditions. Year dummies $\left(\phi_{t}\right)$ capture national trends in inflation and other economic variables. Since the model is written in first-differences, time-invariant factors that are specific to each local authority and that affect the level of house prices have been differenced out. However, results will also be reported including local authority dummies $\left(\rho_{i}\right)$ to capture different trends in house prices at the local level.

The effect of immigration on house prices is identified from spatial correlations between immigrant inflows and changes in house prices across local authorities. There are two potential problems in interpreting these correlations as causal effects. First, immigrant inflows and house prices may be spatially correlated because of common fixed influences, for example, the climate or local amenities. This would lead to a correlation between immigrant inflows and house prices, even in the absence of any genuine effects of immigration. The second problem is that the direction of causality between immigrant inflows and house prices is not clear because immigrants are not randomly allocated across geographic areas. The sign of the bias is difficult to predict ex ante. On the one hand, immigrants may locate in more prosperous areas where house prices are growing faster. On the other hand, it is reasonable to expect that, controlling for economic conditions, immigrants would choose to locate in areas where house prices are growing more slowly.

To address the first problem the model is estimated with the dependent variable in firstdifferences. This eliminates time-invariant, area-specific factors that affect immigration and the level of house prices. To address the second problem I construct an instrument for the recent distribution of the immigrant population based on the historical settlement patterns of immigrants by country of origin. This instrument is commonly used in the literature and is supported by the findings of Bartel (1989) who argues that immigrants in the US tend to locate in areas where immigrant settlement is already strong. It is based on the notion that immigrant networks are an important determinant of the locational choices of new immigrants because they facilitate the job search process and assimilation into a new culture (Munshi 2003).

Specifically, the instrument for the annual inflow of immigrants into local authority $i$ as a share of the population is defined as:

$$
\frac{\sum_{c} \lambda_{c i t_{0}} \Delta F B_{c t}}{P_{o p_{i t-1}}}
$$

where $\lambda_{c i t_{0}}$ is the share of individuals born in foreign region $c$ that live in local authority $i$ in the base year $t_{0}$. This provides a measure of the size of the network from foreign region $c$ in each local authority $i . \Delta F B_{c t}$ is the inflow of immigrants born in foreign region $c$ to the UK as a whole in year $t$. The predicted number of new immigrants from foreign region $c$ in year $t$ that choose to locate in local authority $i$ is $\lambda_{c i t_{0}} \Delta F B_{c t}$. Summing across all regions of origin we obtain a measure of the predicted total immigrant inflow to local authority $i$ in year $t$. I consider nine foreign regions of 
origin: India, EU, Americas and Caribbean, Africa, Other Middle East and Indian sub-continent, Asian, Antarctica and Oceania, Republic of Ireland and other countries.

The validity of this instrument relies on two identification assumptions. First, I assume that the historical settlement pattern of immigrants is uncorrelated with recent changes in the economic performance of different geographic areas. In that case, lagged values of immigrant stocks are correlated with changes in house prices only through their relation with immigrant inflows. The second identifying assumption is the exogeneity of annual changes in the national immigration inflows to the economic conditions of immigrant cities. This is a plausible assumption because the overall number of legal immigrants in the UK should depend on political and administrative decisions.

\section{Data and Descriptive Statistics}

Information on foreign born population by local authority and year is from the UK Labour Force Survey (LFS). The LFS is a household survey, conducted by the Office for National Statistics (ONS) and provides a wide range of data on labour market statistics. It was introduced in 1973 on a biennial basis and has been carried out as a rotating quarterly panel since 1992 with each household being interviewed for five consecutive quarters. Each quarter about 60,000 households are interviewed. Since I do not exploit quarterly variation and to increase the number of observations, I pool all quarters for each year. The standard version of the UK LFS provides regional data by government office region (ten regions in England, plus Wales, Scotland and Northern Ireland). Under an agreement with the ONS, I was granted access to the special license version of the LFS which contains data at the local authority level. This is only available from the first quarter of 2003. To construct the instrument for immigrant inflows I need information on the historical settlement pattern of immigrants with a sufficient time lag. Because the version of the LFS disaggregated by local authority only starts in 2003, I rely on 1991 Census data to construct the historical geographic distribution of immigrants used to build the instrument.

House price data at the local authority level are from the Land Registry. This data set is based on a record of all residential property transactions made in England and Wales since January 1995, whether with cash or with a mortgage. It contains details on over 15 million sales. An index is constructed from these sales data, which is seasonally adjusted and corrects for changes in the quality of housing by using repeated sales. Out of the 15 million sales for which data are collected, just over five million are identifiable matched pairs, providing the basis for the repeated sales regression analysis used to compile the index. This index is then used to construct seasonally adjusted standardized (i.e. corrected for quality) average house prices across local authorities. Standardized average prices are calculated by taking the geometric mean price for each area in April 2000 and using the seasonally adjusted price index to compute average prices back to 1995 and forward to the present day. After combining LFS data with the house price index from the Land Registry, the data set used for the regression analysis covers the period from the first quarter 
of 2003 to the fourth quarter of 2010 and includes 159 local authorities in England and Wales, including all 32 London boroughs. In all estimations I work with a sample of population of working age (16 to 65$)$.

Figure 2 shows the evolution of standardized average house prices in England and Wales since 1995. There was a steady increase in average house prices until the recent financial crisis, from just over $£ 60,000$ in 1995 to nearly $£ 180,000$ in 2007. Average house prices have then declined in 2008 and 2009 and started recovering in 2010. Behind this overall evolution there is substantial variation across local authorities. Table 2 shows the local authorities with the highest average house prices in 2010. The highest prices are registered in London boroughs, with Kensington and Chelsea registering an average price well above $£ 800,000$.

Table 3 contains summary statistics for the main variables used in the analysis. On average, house prices increased 3.7\% per year in England and Wales in the period from 2003 to 2010. There is significant time series and regional variation behind this average. The largest increase in house price was registered in 2004 in Liverpool, Middlesbrough (in North East England) and Carmarthenshire (Wales), where house prices increased by more than $30 \%$. The largest reduction in house prices was registered in 2009, at the height of the financial crisis, in Barking and Dagenham (a borough of London), Knowsley (in Merseyside, North West England) and Neath Port Talbot (Wales). These three regions saw house prices fall by more than $17 \%$ in 2009 .

Turning to immigration flows (the main explanatory variable), the average annual inflow of immigrants across local authorities equals $0.5 \%$ of the initial local population. The largest inflows are registered in London boroughs, where in some years the inflow of immigrants is well above $10 \%$ of the initial local population. Interestingly, the largest outflows are also registered in London boroughs ${ }^{3}$.

\section{Results}

\subsection{Immigration and House Prices}

Table 4 reports the results of estimating equation (11). The dependent variable is the change in the log of the house price index and the main independent variable is the change in the foreign born population relative to the total population in the previous year. Standard errors are heteroskedasticity-robust and are clustered by local authority to account for correlation within groups. The regressions include year fixed effects to capture national trends in inflation and other economic variables. Results are reported with and without local authority fixed effects. Because the model is estimated in first-differences, time-invariant factors that are specific to each local authority and that affect the level of house prices have been differenced out. The inclusion of local authority fixed effects in the model captures different trends in house prices at the local authority level.

\footnotetext{
${ }^{3}$ The maximum value $(28.2 \%$ ) was registered in Islington in 2004 . The minimun value (an outflow of $18.3 \%$ of the initial local population) was registered in Harrow in 2010.
} 
The OLS coefficient is negative and statistically significant. This coefficient cannot be interpreted as the causal effect of immigration on house prices because the locational choice of immigrants is not random. To overcome this problem, I use the settlement pattern of immigrants from the 1991 Census to predict the geographic distribution of immigrants in the current period. Table 5 reports the first stage regression where the dependent variable is the change in the foreign-born population in a local authority over the local population in the previous year. The main explanatory variable is the instrument: the change in the predicted foreign-born population relative to the total initial population. The coefficient is 0.866 and is significant at the $1 \%$ level. This suggests a strong correlation between the current geographic distribution of immigrants and the predicted geographic distribution based on their historical settlement pattern.

The IV estimates are reported in columns 3 and 4 of Table 4 . The results are very similar with and without local authority fixed effects. They suggest that an immigrant inflow equal to $1 \%$ of a local authority's initial population leads to a reduction of 1.6 to $1.7 \%$ in house prices. These estimates are more negative than the ones obtained by OLS suggesting a positive bias in the OLS results. This can be explained by a tendency for immigrants to locate in prosperous areas where house prices are growing faster.

The finding that an immigrant inflow equal to $1 \%$ of a local authority's population reduces house prices by $1.6 \%$ contrasts sharply with studies for other countries which tend to find a positive effect. For example, for the US Saiz (2007) finds that an immigration inflow equal to $1 \%$ of a city's population is associated with an increase in average average prices of 2.9 to $3.4 \%$. For Switzerland Degen and Fischer (2009) find a positive effect of about 2.7\% and for Spain Gonzalez and Ortega (2009) find a positive effect of $3.2 \%$. The underlying model in these studies is one where immigrant inflows increase the demand for housing. Combined with an upward-sloping supply of housing, this would lead to an increase in house prices.

The theoretical model described in Section 2 outlines some channels through which immigration may lead to a reduction in house prices. First, immigration may be associated with offsetting native out-migration. If the offset is complete there would be no change in the size of the local population. Even in this case, house prices may still decrease if the wage of natives who leave is higher than the wage of immigrants who come into the city. For example, suppose that for each immigrant that enters a region one native moves out and that natives who move out have higher wages. In this case, even though the size of the local population does not change, there is a reduction in local wealth which would lead to a reduction in housing demand and house prices in areas where immigrants settle.

A second reason why immigration may generate a negative effect on house prices is if immigrants and natives are substitutes in production. In this case, an immigrant inflow would lead to a reduction in native wages. Provided immigrant wages are not large enough to compensate for the reduction in native wages, local wealth would decrease generating a reduction in house prices.

To understand the mechanism behind the negative effect of immigration on local house prices, I look at how immigration affects native population growth and mobility and the wages of the local 
population.

\subsection{Immigration and Native Population Growth and Mobility}

Since the UK-born have very low emigration rates, at the national level each additional immigrant adds one person to the total population. At the local level, however, there are substantial movements of population that can potentially offset immigrant inflows.

To study the effect of immigration on native population growth, I follow Card (2007) and estimate the following model of the relation between the changes in the native and immigrant populations divided by the initial total population stock:

$$
\frac{\Delta N_{i t}}{P o p_{i t-1}}=\beta \frac{\Delta F B_{i t}}{\text { Pop }_{i t-1}}+\phi_{t}+\rho_{i}+\varepsilon_{i t}
$$

Year dummies $\left(\phi_{t}\right)$ capture national trends in native population growth and other economic variables and local authority dummies $\left(\rho_{i}\right)$ capture different trends in native population growth at the local authority level.

Because total population equals the sum of native and immigrant population $\left(\right.$ Pop $_{i t}=N_{i t}+$ $\left.F B_{i t}\right)$, the growth rate of the total population can be written as:

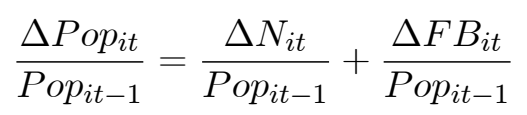

Substituting this into equation (13) gives a relation between the growth rate of total population and the immigration inflow:

$$
\frac{\Delta \text { Pop }_{i t}}{\text { Pop }_{i t-1}}=(1+\beta) \frac{\Delta F B_{i t}}{\text { Pop }_{i t-1}}+\phi_{t}+\rho_{i}+\varepsilon_{i t}
$$

In this model the coefficient $\beta$ capture the effect of immigrant inflows on native population growth. A value of $\beta=0$ means that immigrant inflows are not offset by native outflows and each additional immigrant adds 1 to the total population. A value of $\beta=-1$ means that immigrant inflows are completely offset by native outflows.

Model (13) suffers from the same endogeneity problem as model (11), i.e. the fact that the location choices of immigrants are not random. In this case the sign of the bias is easier to predict: the unobserved factors that lead to larger native population growth (the factors captured by the error term) are also likely to lead to larger immigrant inflows, generating an upward-biased estimate of $\beta$. I address this problem using the same instrument as in model (11): the predicted immigrant inflow based on the historical settlement pattern of immigrants in 1991 divided by the initial population.

Table 6 reports the results of estimating model (13) by OLS and IV. The OLS coefficient is positive and significant, but the IV coefficient is negative. As expected, there is a positive bias in the OLS coefficient since the unobserved factors that make a local area more attractive to natives also 
make it more attractive to immigrants. Once this endogeneity is taken into account, the coefficient becomes negative and suggests that an immigrant inflow equal to $1 \%$ of an area's initial population leads to a native outflow equal to $0.849 \%$ of the area's initial population. Hence, total population in the area would increase by only $0.151 \%$ in response to a $1 \%$ immigrant inflow.

Another way to study the response of the native population to immigration is to look at inmigration and out-migration rates. Using information on net migration between 11 government office regions in the UK from National Health Service registration flow data, Hatton and Tani (2005) show that there is a negative correlation between immigration to one region from abroad and in-migration from other regions. But this is only significant for the southern regions where immigration of foreign citizens is most concentrated.

The LFS contains information on the region of residence one year ago at the local authority level. Using this information, I compute in-migration, out-migration and net migration rates for the native population. A native is classified as having moved out of local authority $i$ if he lived in that local authority in year $t-1$ and lives in a different local authority in year $t$. The out-migration rate is defined as the number of natives who moved out of local authority $i$ between years $t-1$ and $t$ divided by the native population of local authority $i$ in year $t-1$. Similarly, a native is classified as having moved into local authority $i$ if he lives there in year $t$ and lived in a different local authority in $t-1$. The in-migration rate is obtained by dividing the number of natives who moved into local authority $i$ by the population of $i$ in $t-1$. The net out-migration rate is simply the difference between the out-migration and the in-migration rates.

The following model is used to examine the effect of immigration on native out-migration, in-migration and net out-migration rates:

$$
\text { mobility }_{i t}=\beta \frac{\Delta F B_{i t}}{P o p_{i t-1}}+\phi_{t}+\rho_{i}+\varepsilon_{i t}
$$

The dependent variable is the native out-migration, in-migration or net out-migration rate. The coefficient $\beta$ can be interpreted as the change in these mobility rates generated by an immigration inflow equal to $1 \%$ of the local authority's population. As for the growth rate of native population, this model suffers from an endogeneity problem, since the unobservable factors that lead natives to move into a region may also attract immigrants into that region. To account for this problem, the model is estimated with the usual instrument based on the historical settlement pattern of immigrants.

Table 7 reports the results for the effect of immigration on native mobility rates. An immigrant inflow equal to $1 \%$ of the local initial population increases the native out-migration rate by 0.132 percentage points. This is quite a large effect since the average native out-migration rate for the UK is only $2.7 \%$. Immigration also increases native in-mobility rates, but the effect is much smaller at 0.035 percentage points. The coefficient on net out-migration equals the difference between the coefficients on out-migration and in-migration rates. On the whole, these results are consistent with the ones obtained for native population growth and suggest that immigrant inflows are partly offset by native outflows. 


\subsection{Immigration and Native Wages}

Another channel highlighted by the model in Section 2 through which immigration may affect house prices is via its effect on native wages. If immigrants and natives are substitutes in production, immigration should have a negative effect on native wages. On the other hand, if they are complements immigration should have a positive effect on native wages.

Using an approach similar to Dustmann, Frattini and Preston (2008), I study the effect of immigration on native wages at different points in the native wage distribution. This study shows that if immigrants are placed in the wage distribution according to predicted wages based on their age and education, they would be located at the upper and middle part of the wage distribution. However, if they are placed in the wage distribution according to their observed wage, they are at the lower end of this distribution. It is then plausible that immigration depresses native wages at the lower end of the wage distribution because immigrants and lower wage natives are substitutes in production.

To test this in my data, I use information on gross hourly wages from the LFS. To reduce the impact of outliers, the sample is trimmed to include observations between the $1^{\text {st }}$ and $99^{\text {th }}$ percentiles of the wage distribution in each year. I then regress first differences in the log of the percentile $p$ of native wages across different local authorities in the UK on the fraction of new immigrants in the initial population, year fixed effects and local authority fixed effects:

$$
\Delta \ln \left(w_{i p t}\right)=\beta_{p} \frac{\Delta F B_{i t}}{\text { Pop }_{i t-1}}+\phi_{t}+\rho_{i}+\varepsilon_{i t}
$$

The model is estimated separately for the $25^{\text {th }}, 50^{\text {th }}$ and $75^{\text {th }}$ percentiles of the native wage distribution. To overcome the problem of endogenous allocation of immigrants into particular regional labour markets, I use the instrument given in equation (12) based on the settlement pattern of previous immigrants.

The results, reported in Table 8, suggest that immigration has a negative but largely insignificant effect on native wages. The effect is only significant in the IV regression for the $25^{\text {th }}$ percentile, suggesting that an immigration inflow equal to $1 \%$ of the region's initial population reduces the $25^{t h}$ percentile of native wages by $0.26 \%$. This effect is similar to the one found in Dustmann, Frattini and Preston (2008).

\subsection{Immigration and the Wage Distribution of the Local Population}

The findings on native population growth and mobility suggest that immigration into a local area is partly offset by native outflows. This change in the composition of the local population may have implications for the income distribution and hence for house prices. For example, if immigrants have lower income than natives, an inflow of immigrants and an outflow of natives would depress income in the local area and should lead to a reduction in demand for housing and in house prices.

To look at the effect of immigration on the income distribution of the local population, I compute the four quartiles of the national wage distribution for the total population (immigrants 
and natives) in each year ${ }^{4}$. In 2010 the $25^{\text {th }}$ percentile of the national wage distribution was $£ 7.2$ per hour, the median was $£ 10.2$ and the $75^{\text {th }}$ percentile was $£ 15.5$. Following Card (2007), I define the following fractions:

- $\pi_{i q t}, q=1,2,3,4$ is the fraction of all residents (natives and immigrants) in local authority $i$ that have wages in each of the four quartiles of the national wage distribution in year $t$.

- $p_{q t}^{U K}, q=1,2,3,4$ is the fraction of all natives at the national level that have wages in each of the four quartiles of the national wage distribution in year $t$. Because the large majority of the population is UK-born, $p_{q t}^{U K}$ should be close to 0.25 .

- $p_{\text {iqt }}, q=1,2,3,4$ is the fraction of all native residents in local authority $i$ that have wages in each of the four quartiles of the national wage distribution in year $t$.

- $q_{q t}^{U K}, q=1,2,3,4$ is the fraction of all immigrants at the national level that have wages in each of the four quartiles of the national wage distribution in year $t$.

- $q_{i q t}, q=1,2,3,4$ is the fraction of all immigrant residents in local authority $i$ that have wages in each of the four quartiles of the national wage distribution in year $t$.

In the absence of immigration or any differential sorting of the native population across local authorities, the fraction of all residents in each quartile should be similar to the fraction of natives at the national level in each quartile, i.e., $\pi_{i q t} \simeq p_{j t}^{U K} \simeq 0.25$. Letting $f_{i t}$ denote the share of immigrants in the population in local authority $i$ in year $t$, the deviation from this counterfactual can be written as the sum of three terms:

$$
\pi_{i q t}-p_{q t}^{U K}=f_{i t}\left(q_{q t}^{U K}-p_{q t}^{U K}\right)+f_{i t}\left(q_{i q t}-q_{q t}^{U K}\right)+\left(1-f_{i t}\right)\left(p_{i q t}-p_{q t}^{U K}\right)
$$

The first term is a composition effect: if the national fraction of immigrants in each skill group ( $\left.q_{q t}^{U K}\right)$ differs from the national fraction of natives $\left(p_{q t}^{U K}\right)$, regions with more immigrants will tend to be further away from the counterfactual share $p_{j t}^{U K}$. The second term captures the local selectivity of the immigrant population: if region $i$ has more immigrants in wage group $q$ than the national average, the fraction of the total population in wage group $q$ in region $i\left(\pi_{i q t}\right)$ will also be larger. The third term is similar and captures the local selectivity of the native population.

To see how immigration affects the wage distribution of the local population, I regress each component in equation (16) on the share of immigrants in the population at the local level $\left(f_{i t}=\right.$ $\left.\frac{F B_{i t}}{P o p_{i t}}\right)$ and a set of local authority and year fixed effects. This is done separately for each quartile of the wage distribution. The results are reported in Table 9 . Note that, because equation (16) holds identically, the coefficients in columns 2 to 4 add up to the coefficient in column 1.

Overall, there is a strong positive relation between the fraction of immigrants in a local authority and the fraction of residents in the lowest wage quartile, attributable mainly to the native selectivity

\footnotetext{
${ }^{4}$ As before, the sample is trimmed to include observations between the $1^{\text {st }}$ and $99^{\text {th }}$ percentiles of the wage distribution in each year. This reduces the impact of outliers.
} 
effect. Specifically, a 10 percentage point increase in the local fraction of immigrants is associated with a 2 percentage points increase in the fraction of the population in wage quartile 1 , of which 0.4 percentage points is attributable to the pure composition effect, 0.3 percentage points is attributable to the fact that the immigrant population tends to be have smaller wages in high immigration cities, and 1.3 percentage points is attributable to the fact that the native population tends to have smaller wages in high immigration cities. Similarly, there is a negative relation between the fraction of immigrants in a local authority and the fraction of residents in the highest wage quartile. Again, this is mostly due to the fact that the native population tends to have smaller wages in high immigration cities.

These results could be driven by two factors. First, immigration could be driving down native wages. Second, natives who leave high immigration cities could be the ones at the top of the wage distribution. I have already presented some evidence that immigration has a negative effect on native wages at the lower end of the wage distribution. To test whether natives who leave the city are at the top of the wage distribution, I work with individual-level data for natives and look at whether the probability of being in each of the four quartiles of the wage distribution is different for those who leave the city and those who stay. In particular, the following logit model is estimated separately for each quartile $q$ of the native wage distribution $(q=1,2,3,4)$ :

$$
D_{j q t}=\Lambda\left[\beta_{q} \text { moved }_{j t}+\phi_{t}+\rho_{i}\right]+\varepsilon_{i t}
$$

The dependent variable $D_{j q t}$ is an indicator equal to 1 if native $j$ earns a gross hourly wage in quartile $q$ of the wage distribution and 0 otherwise. The independent variable of interest is moved $_{j t}$, which is an indicator equal to 1 if native $j$ moved to a different local authority between periods $t-1$ and $t$. This variable is constructed using the LFS and is based on the local authority of residence at the time of the survey and one year ago (the same data used to construct mobility rates). The model includes year and local authority fixed effects.

Table 10 reports the results of estimating this model for each quartile of the wage distribution. There is some evidence that natives who move to a different local authority are more likely to be in the upper quartiles of the wage distribution, Specifically, natives who move to a different local authority have a probability of being in the first quartile of the wage distribution that is 9.6 percentage points lower than that of natives who do not move. The probability of being in the third quartile of the wage distribution is 12.4 percentage points higher for natives who move than for those who stay. This suggests that native out-mobility leads to a reduction in income at the local level which pushes down house prices via the income effect.

The finding that natives who move to a different local authority tend to be at the top half of the wage distribution combined with the finding that immigration does not depress wages in that part of the wage distribution suggests that native out-mobility is not being driven by a reduction in wages. Looking at the determinants of native out-mobility in equation (9), the empirical results suggest that immigration has no effect on wages of natives at the top of the wage distribution $\left(\rho_{H}=0\right)$ and has a negative effect on house prices $\left(\frac{d P}{d I}<0\right)$. This implies that native out-mobility 
is driven by other factors which are captured by a negative preference for immigration $(\delta>0)$.

\subsection{Immigrant Education and the Effect of Immigration on House Prices}

The model in Section 2 predicts that immigration is more likely to have a negative effect on house prices in regions where immigrant wages are low. This is because high immigrant wages would push up housing demand via the income effect.

To test this hypothesis, I use information on the highest qualification attained by immigrants from the LFS. I focus on education rather than wages to avoid potential endogeneity between house prices and wages. There could be unobserved factors which simultaneously affect house prices and wages. Also, if immigrants work in the construction sector, a boom in house prices may lead to an increase in immigrant wages generating reverse causality. Working with education gets around these problems.

For each year and local authority, I calculate the percentage of immigrants with a level of education below the General Certificate of Secondary Education (GCSE) or equivalent. In 2010, $46.4 \%$ of immigrants in England and Wales had a level of education lower than GCSE or equivalent. For natives this percentage is lower at 20.5\%. Local authorities are divided in four groups based on the quartiles of the regional distribution of the share of immigrants with lower education (below GCSE). To test whether the negative effect of immigration on house prices is larger in regions where immigrants have lower education, model (11) is estimated separately for each of these four groups of local authorities. Table 11 reports OLS and IV results with the usual instrument based on the historical settlement pattern of immigrants.

The results support the hypothesis that immigration has a more negative effect on house prices in regions where immigrants have lower education. For regions where the share of immigrants with lower education is low (quartiles 1 and 2), immigration has no significant effect on house prices. The effect becomes negative and significant as the share of immigrants with lower education increases. The IV results suggest that an inflow of immigrants equal to $1 \%$ of the initial local population reduces house prices by $1.4 \%$ for local authorities in quartile 3 and by $1.8 \%$ for local authorities in quartile 4. Consistent with the intuition of the model in Section 2, the negative effect of immigration on house prices is driven by regions where immigrants have lower education.

\section{$6 \quad$ Results with aggregated regions}

The mobility response of natives presents challenges when trying to derive implications of our results for the national economy. Native out-migration has a negative income effect on housing demand in local areas. However, natives who move push up housing demand in the local areas that they move into. An analysis of the effects of immigration with broader regions is likely to point

to a small effect of immigration on house prices because the effects of immigration are diffused throughout the region.

The consequences of the mobility response of natives for the validity of the spatial correlations 
approach are discussed in Borjas (2006). He points out that natives may respond to the entry of immigrants into a local labor market by moving to other localities until native wages are again equalized across areas. An inter-region comparison of the wage of native workers might show little or no difference because the effects of immigration are diffused throughout the region, and not because immigration had no economic effects. Using data from the US 1960-2000 decennial censuses, Borjas finds that immigration is associated with lower in-migration rates, higher out-migration rates, and a decline in the growth rate of the native workforce. The native migration response attenuates the measured impact of immigration on wages in a local labor market, particularly when the labor market is defined at a more aggregated level, such as the state rather than metropolitan area.

To test whether this is also the case in my analysis, I estimate equation (11) using broader regions. Instead of considering 159 local authorities across England and Wales, I work with only 10 government office regions: North East, North West, Yorkshire and Humberside, East Midlands, West Midlands, East, London, South East, South West and Wales. As before, immigration data are from the LFS and house price data are from the Land Registry. The data set covers the period from 1996 to 2009. To overcome endogeneity in the locational choices of immigrants, the usual instrument based on their historical settlement pattern is used. Table 12 reports OLS and IV results. The first stage results are reported in Table 13 and confirm the validity of the instrument with this broader definition of regions.

The estimates are more imprecise because the sample is much smaller. There is no evidence that immigration has any effect on house prices once regions are aggregated to this level. This is consistent with the analysis in Borjas (2006) and suggests that native mobility may diffuse the effects of immigration throughout these broad regions. Immigration may have important economic effects at the local level which are only captured when the labour market is defined at a sufficiently disaggregated level.

\section{Conclusion}

There is a growing body of literature looking at the effect of immigration on house prices in different countries. This is an important dimension of the economic effects of immigration given the large weight that housing consumption has on the household budget. This article contributes to the immigration literature by estimating the effect of immigration on house prices in the UK and highlighting the channels through which this effect takes place.

Using data on immigration and house prices for 159 local authorities in England and Wales, I find that immigration has a negative effect on house prices. An inflow of immigrants equal to $1 \%$ of the local population reduces house prices by $1.6 \%$. A simple theoretical model and my empirical estimates on native population growth and mobility suggest that one explanation for this negative effect is the mobility response of natives. The estimates show that an immigrant inflow equal to $1 \%$ of the local population leads to a native outflow equal to $0.849 \%$ of the local population and increases the native out-migration rate by 0.132 percentage points. 
Looking at the wage distribution of the local population, I find that local areas with high immigration tend to be at the bottom of the wage distribution. This is mostly due to the fact that natives have lower wages in high immigration cities. This finding can be explained by two factors. First, there is some evidence that immigration has a negative effect on native natives at the lower end of the wage distribution. Second, natives who leave the city are at the top of the wage distribution. This generates a negative income effect on housing demand and pushes down house prices in local areas where immigrants cluster.

Behind these overall effects, there are some important differences depending on the level of education of the local immigrant population. The negative effect of immigration on house prices is driven by areas where the share of immigrants with lower education is high. This is consistent with the intuition from the theoretical model which suggests that, in local areas where immigrants are more educated (and hence have higher wages), immigration exerts a positive income effect on housing demand which counteracts the negative income effect from native out-mobility. 


\section{References}

[1] Akbari, A and Aydede, Y (2009), 'Effects of Immigration on Housing Prices in Canada', Atlantic Metropolis Centre Working Paper 24-2009.

[2] Bartel, A (1989), 'Where do the New U.S. Immigrants Live?', Journal of Labor Economics, vol. 7 , pp. 371-91.

[3] Borjas, G (2006), 'Native Internal Migration and the Labor Market Impact of Immigration', The Journal of Human Resources, vol. 41, no. 2 pp. 221-258.

[4] Card, D (2007), 'How Immigration Affects US Cities', CReAM Discussion Paper 11/07.

[5] Degen, K and Fischer, A (2009), 'Immigration and Swiss House Prices', CEPR Discussion Paper 7583.

[6] Dustmann, C, Fabbri, F and Preston, I (2005), 'The Impact of Immigration on the British Labour Market', The Economic Journal, vol. 115 (November), pp. F324-F341.

[7] Dustmann, C, Frattini, T and Preston, I (2008), 'The Effect of Immigration along the Distribution of Wages', CReAM Discussion Paper 03/08.

[8] Dustmann, C and Glitz, A (2005), 'Immigration, Jobs and Wages: Theory, Evidence and Opinion', CEPR/CReAM publication, London.

[9] Favara, G and Imbs, J (2010), 'Credit Supply and the Price of Housing', CEPR Discussion Paper 8129.

[10] Glaeser, E, Gyourko, J and Saiz, A (2008), 'Housing Supply and Housing Bubbles', Harvard Institute of Economic Research Discussion Paper 2158.

[11] Gonzalez, L and Ortega, F (2009), 'Immigration and Housing Booms: Evidence from Spain', CReAM Discussion Paper 19/09.

[12] Hatton, T and Tani, M (2005), 'Immigration and Inter-regional Mobility in the UK: 1982-2000', The Economic Journal, vol. 115 (November), pp. F342-F358.

[13] House of Lords report (2008), 'The Economic Impact of Immigration'.

[14] Munshi, K (2003), 'Networks in the Modern Economy: Mexican Migrants in the US Labor Market', Quarterly Journal of Economics, vol. 118, pp. 549-99.

[15] Ottaviano, G and Peri, G (2007), 'The Effects of Immigration on U.S. Wages and Rents: a General Equilibrium Approach', CReAM Discussion Paper 13/07.

[16] Saiz, A (2007), 'Immigration and Housing Rents in American Cities', Journal of Urban Economics, vol. 61, pp. 345-371. 
[17] Stillman, S and Maré, D (2008), 'Housing Markets and Migration: Evidence from New Zealand', Motu Working Paper 08-06. 
Figure 1. Percentage of immigrants in the population

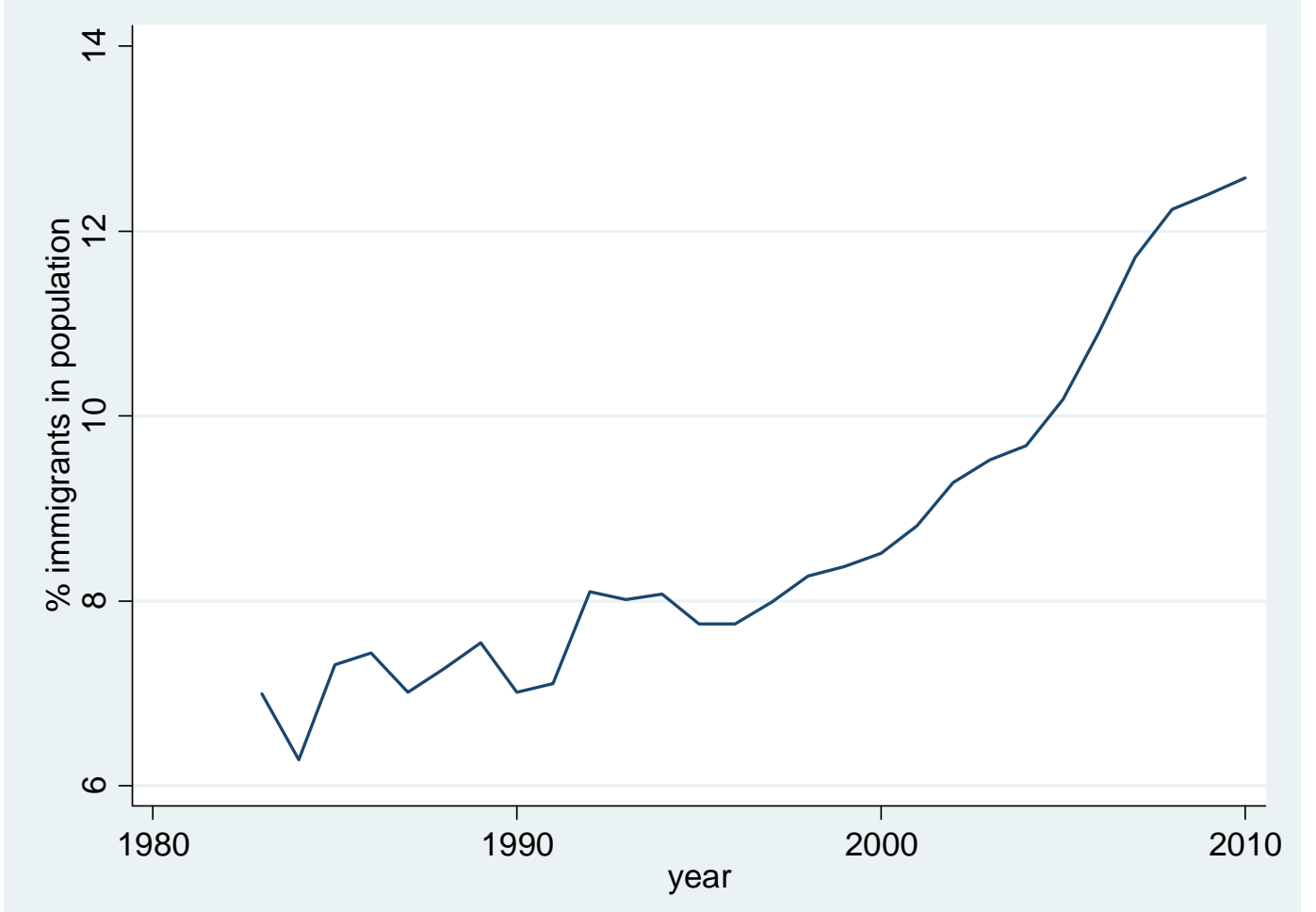

Source: UK Labour Force Survey

Figure 2. Average house prices in England and Wales

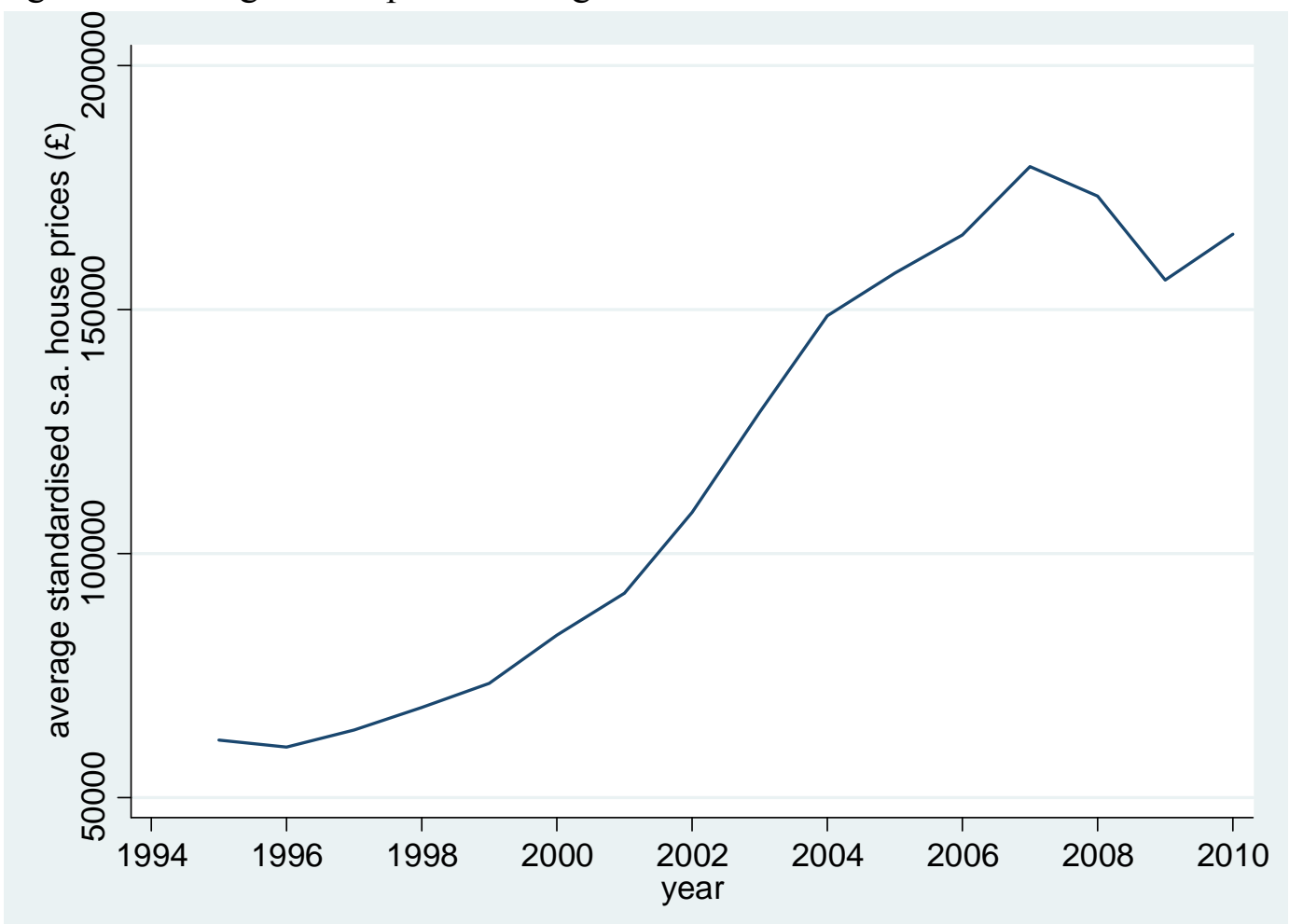

Source: Land Registry 
Table 1. Local authorities with the largest concentration of immigrants in 2010

\begin{tabular}{llll}
\hline \hline \multicolumn{3}{l}{$\begin{array}{l}\text { Percentage of immigrants in the population } \\
\text { London }\end{array}$} & \multicolumn{2}{l}{ Outside London } \\
Westminster & 63.7 & Leicester & 40.8 \\
Newham & 62.4 & Luton & 35.3 \\
Brent & 58.6 & Slough & 33.6 \\
Ealing & 52.7 & Milton Keynes & 29.7 \\
Kensington and Chelsea & 51.3 & Manchester & 29.1 \\
Tower Hamlets & 50.6 & Birmingham & 24.9 \\
Hounslow & 50.5 & Reading & 23.3 \\
Haringey & 48.5 & Coventry & 22.3 \\
Merton & 47.0 & Peterborough & 22.0 \\
Harrow & 46.3 & Rochdale & 21.1 \\
\hline \hline
\end{tabular}

Source: UK Labour Force Survey

Table 2. Local authorities with highest house prices in 2010

\begin{tabular}{lrll}
\hline \hline \multicolumn{2}{l}{$\begin{array}{l}\text { Average standardised house prices }(f) \\
\text { London }\end{array}$} & & \\
Kensington and Chelsea & $873,071.3$ & Outside London & \\
Westminster & $623,542.4$ & Surrey & $322,359.1$ \\
Camden & $546,056.3$ & Wokingham & $296,963.9$ \\
Hammersmith and Fulham & $495,451.0$ & Buckinghamshire & $271,856.9$ \\
Richmond upon Thames & $439,709.9$ & Hertfordshire & $256,757.1$ \\
Islington & $430,073.3$ & Oxfordshire & $239,770.9$ \\
Wandsworth & $381,705.1$ & Bath and North East Somerset & $229,796.5$ \\
Southwark & $367,191.2$ & West Berkshire & $226,932.1$ \\
Hackney & $365,235.3$ & Brighton and Hove & $221,496.2$ \\
Barnet & $346,038.8$ & Dorset & $215,243.6$ \\
\hline \hline
\end{tabular}

Source: Land Registry

Table 3. Descriptive statistics (2003-2010)

\begin{tabular}{|c|c|c|c|c|c|}
\hline Variable & Observations & Mean & Std. Dev. & Min & Max \\
\hline $\begin{array}{l}\Delta \log \text { house price index } \\
\Delta \mathrm{FB}_{\mathrm{it}} / \mathrm{Pop}_{\mathrm{it}-1}\end{array}$ & $\begin{array}{l}1113 \\
1113 \\
\end{array}$ & $\begin{array}{l}0.037 \\
0.005 \\
\end{array}$ & $\begin{array}{l}0.088 \\
0.037 \\
\end{array}$ & $\begin{array}{l}-0.178 \\
-0.183 \\
\end{array}$ & $\begin{array}{l}0.312 \\
0.282 \\
\end{array}$ \\
\hline $\begin{array}{l}\Delta \mathrm{N}_{\text {it }} / \mathrm{Pop}_{\mathrm{it}-1} \\
\text { Native out-migration rate } \\
\text { Native in-migration rate } \\
\text { Native net out-migration rate } \\
\text { Share of immigrants with low education } \\
\text { (below GCSE) }\end{array}$ & $\begin{array}{l}1113 \\
1360 \\
1360 \\
1360\end{array}$ & $\begin{array}{r}-0.001 \\
0.027 \\
0.025 \\
0.002\end{array}$ & $\begin{array}{l}0.093 \\
0.045 \\
0.030 \\
0.041\end{array}$ & $\begin{array}{r}-0.316 \\
0.000 \\
0.000 \\
-0.174\end{array}$ & $\begin{array}{l}0.377 \\
0.683 \\
0.259 \\
0.587\end{array}$ \\
\hline$\Delta\left(\right.$ Employment $_{\text {it }} /$ Population $\left._{\text {it }}\right)$ & 1113 & -0.003 & 0.032 & -0.138 & 0.115 \\
\hline
\end{tabular}


Table 4. Immigrant inflows and annual log house price changes - 2004-2010

\begin{tabular}{|c|c|c|c|c|}
\hline & \multicolumn{4}{|c|}{$\Delta \log$ house price index } \\
\hline & (1) & $(2)$ & (3) & (4) \\
\hline & \multicolumn{2}{|c|}{ OLS } & \multicolumn{2}{|c|}{ IV } \\
\hline$\Delta \mathrm{FB}_{\mathrm{it}} / \mathrm{Pop}_{\mathrm{it}-1}$ & $\begin{array}{c}-0.184 * * * \\
(0.032)\end{array}$ & $\begin{array}{c}-0.172 * * * \\
(0.036)\end{array}$ & $\begin{array}{c}-1.717 * * \\
(0.829)\end{array}$ & $\begin{array}{c}-1.627 * * * \\
(0.366)\end{array}$ \\
\hline$\Delta\left(\right.$ Employment $_{\text {it }} /$ Population $\left._{\text {it }}\right)$ & $\begin{array}{c}0.121 * * * \\
(0.042)\end{array}$ & $\begin{array}{c}0.115 * * * \\
(0.044)\end{array}$ & $\begin{array}{c}0.044 \\
(0.077)\end{array}$ & $\begin{array}{c}0.053 \\
(0.073)\end{array}$ \\
\hline Observations & 1113 & 1113 & 1113 & 1113 \\
\hline R-squared & 0.790 & 0.814 & 0.397 & 0.499 \\
\hline Local authority fixed effects & No & Yes & No & Yes \\
\hline
\end{tabular}

Notes: Robust standard errors clustered by local authority in parentheses. $\Delta$ indicates first difference. Regressions include year fixed effects.

$\begin{array}{ll}* * * & \text { significant at } 1 \% \\ * * & \text { significant at } 5 \% \\ * & \text { significant at } 10 \%\end{array}$

Table 5. First stage regression

\begin{tabular}{cc}
\hline \hline & $\Delta \mathrm{FB}_{\text {it }} / \mathrm{Pop}_{\text {it-1 }}$ \\
\hline instrument & $0.866^{* * *}$ \\
& $(0.284)$ \\
\hline Observations & 1113 \\
\hline \hline
\end{tabular}

Notes: Robust standard errors clustered by local authority in parentheses. $\Delta$ indicates first difference. Regressions include year and local authority fixed effects and the change in the employment to population ratio. The instrument is the change in the predicted foreign-born population relative to the total initial population. It uses the settlement pattern of immigrants in the 1991 Census to predict the number of foreign-born in each local authority in the current period.
$* * * \quad$ significant at $1 \%$
** $\quad$ significant at $5 \%$
* $\quad$ significant at $10 \%$ 
Table 6. Immigrant inflows and change in native population

\begin{tabular}{lcc}
\hline \hline & \multicolumn{3}{c}{$\Delta \mathrm{N}_{\mathrm{it}} / \mathrm{Pop}_{\mathrm{it}-1}$} \\
\hline & $(1)$ & $(2)$ \\
& $\mathrm{OLS}$ & $\mathrm{IV}$ \\
\hline$\Delta \mathrm{FB}_{\mathrm{it}} / \mathrm{Pop}_{\mathrm{it}-1}$ & $0.229^{* * *}$ & $-0.849^{*}$ \\
& $(0.079)$ & $(0.469)$ \\
\hline Observations & 1113 & 1113 \\
R-squared & 0.341 & 0.188 \\
\hline \hline
\end{tabular}

Notes: Robust standard errors clustered by local authority in parentheses. $\Delta$ indicates first difference. Regressions include year and local authority fixed effects.
*** $\quad$ significant at $1 \%$
** $\quad$ significant at $5 \%$
* $\quad$ significant at $10 \%$

Table 7. Immigrant inflows and native mobility

\begin{tabular}{lcccccc}
\hline \hline & \multicolumn{2}{c}{ Native out-migration rate } & \multicolumn{2}{c}{ Native in-migration rate } & \multicolumn{2}{c}{ Native net out-migration rate } \\
\hline & $(1)$ & $(2)$ & $(3)$ & $(4)$ & $(5)$ & $(6)$ \\
& OLS & IV & OLS & IV & OLS & IV \\
\hline$\Delta \mathrm{FB}_{\text {it }} / \mathrm{Pop}_{\mathrm{it}-1}$ & $0.111^{* * *}$ & $0.132^{* * *}$ & $0.032^{* *}$ & $0.035^{*}$ & $0.080^{* * *}$ & $0.097^{* * *}$ \\
& $(0.024)$ & $(0.021)$ & $(0.014)$ & $(0.020)$ & $(0.025)$ & $(0.021)$ \\
\hline Observations & 1360 & 1256 & 1360 & 1256 & 1360 & 1256 \\
R-squared & 0.637 & 0.646 & 0.627 & 0.639 & 0.388 & 0.408 \\
\hline \hline
\end{tabular}

Notes: Robust standard errors clustered by local authority in parentheses. $\Delta$ indicates first difference. Regressions include year and local authority fixed effects.

*** $\quad$ significant at $1 \%$

** $\quad$ significant at $5 \%$

* $\quad$ significant at $10 \%$ 
Table 8. Immigration and native wages

\begin{tabular}{lcccccc}
\hline \hline & \multicolumn{2}{l}{$\Delta \ln ($ wage $)$} & \multicolumn{2}{c}{$\Delta \ln$ (wage) } & \multicolumn{2}{c}{$\Delta \ln ($ wage $)$} \\
& \multicolumn{2}{c}{ percentile 0.25} & \multicolumn{2}{c}{ percentile 0.5} & \multicolumn{2}{c}{ percentile 0.75} \\
& $(1)$ & $(2)$ & $(3)$ & $(4)$ & $(5)$ & $(6)$ \\
& OLS & IV & OLS & IV & OLS & IV \\
\hline$\Delta$ FB $_{\text {it }} /$ Pop $_{\text {it-1 }}$ & -0.079 & $-0.260^{*}$ & -0.059 & -0.190 & -0.070 & -0.020 \\
& $(0.082)$ & $(0.155)$ & $(0.070)$ & $(0.150)$ & $(0.092)$ & $(0.222)$ \\
\hline Observations & 1113 & 1113 & 1113 & 1113 & 1113 & 1113 \\
R-squared & 0.067 & 0.051 & 0.063 & 0.054 & 0.047 & 0.046 \\
\hline \hline
\end{tabular}

Notes: Coefficients reported are from regressions of the first difference in the log of native wages at the indicated percentiles of the distribution of native wages on the change in foreign-born population relative to the local initial population. Robust standard errors clustered by local authority in parentheses. Regressions include year and local authority fixed effects.

$\begin{array}{ll}* * * & \text { significant at } 1 \% \\ * * & \text { significant at } 5 \% \\ * & \text { significant at } 10 \%\end{array}$

Table 9. Immigration and wage distribution of the local population

(1)

Excess fraction in wage group

$\pi_{i q t}-p_{q t}^{U K}$
(2)

Composition effect

$f_{i t}\left(q_{q t}^{U K}-p_{q t}^{U K}\right)$
(3)

Selectivity of immigrants
(4)

Selectivity of natives

\begin{tabular}{lcccc}
\hline Quartile 1 & $0.204 * * *$ & $0.042^{* * *}$ & 0.033 & $0.130^{* * *}$ \\
& $(0.044)$ & $(0.008)$ & $(0.027)$ & $(0.041)$ \\
R-squared & 0.825 & 0.647 & 0.606 & 0.798 \\
\hline Quartile 2 & -0.054 & $-0.016^{* * *}$ & -0.033 & -0.005 \\
& $(0.046)$ & $(0.002)$ & $(0.025)$ & $(0.041)$ \\
R-squared & 0.666 & 0.825 & 0.415 & 0.616 \\
\hline Quartile 3 & -0.066 & $-0.024 * * *$ & 0.004 & -0.045 \\
& $(0.048)$ & $(0.004)$ & $(0.022)$ & $0.053)$ \\
R-squared & 0.411 & 0.744 & 0.352 & 0.365 \\
\hline Quartile 4 & $-0.085 * *$ & -0.001 & -0.004 & -0.080 \\
& $(0.043)$ & $(0.005)$ & $0.041)$ & $0.059)$ \\
\hline R-squared & 0.910 & 0.602 & 0.727 & 0.888 \\
\hline Observations & 1321 & 1321 & 1321 & 1321 \\
\hline \hline
\end{tabular}

Notes: Coefficients reported are from regressions of the variable indicated in the column heading for each quartile of the wage distribution on the share of immigrants in the local population. Robust standard errors clustered by local authority in parentheses. Regressions include year and local authority fixed effects.

$\begin{array}{ll}* * * & \text { significant at } 1 \% \\ * * & \text { significant at } 5 \% \\ * & \text { significant at } 10 \%\end{array}$ 
Table 10. Native mobility and wage distribution

(2)

(3)

(4)

wage in quartile 1 wage in quartile 2 wage in quartile 3 wage in quartile 4

\begin{tabular}{lcccc}
\hline Moved & $-0.096^{*}$ & 0.028 & $0.124^{* *}$ & -0.063 \\
& $(0.055)$ & $(0.055)$ & $(0.052)$ & $(0.061)$ \\
\hline Observations & 86129 & 86129 & 86129 & 86129 \\
\hline \hline
\end{tabular}

Notes: Coefficients reported are from logit regressions for each quartile of the native wage distribution. The dependent variable is an indicator equal to one if the native earns a wage in the indicated quartile of the distribution. The independent variable of interest is an indicator equal to one if the native has moved to a different local authority between consecutive years. Robust standard errors clustered by local authority in parentheses. Regressions include year and local authority fixed effects.

$* * * \quad$ significant at $1 \%$

** $\quad$ significant at $5 \%$

* $\quad$ significant at $10 \%$

Table 11. Immigrant education and the effect of immigration on house prices

\begin{tabular}{lcccccccc}
\hline \hline & \multicolumn{9}{c}{$\Delta$ log house price index } \\
\hline & $(1)$ & $(2)$ & \multicolumn{2}{c}{$(1)$} & $(2)$ & $(1)$ & $(2)$ & \multicolumn{2}{c}{$(1)$} & $(2)$ \\
& Quartile 1 & \multicolumn{2}{c}{ Quartile 2 } & \multicolumn{2}{c}{ Quartile 3 } & \multicolumn{2}{c}{ Quartile 4 } \\
& OLS & IV & OLS & IV & OLS & IV & OLS & IV \\
\hline$\Delta \mathrm{FB}_{\text {it }} /$ Pop $_{\text {it-1 }}$ & -0.004 & 0.632 & -0.126 & -0.880 & -0.155 & $-1.358^{* * *}$ & $-0.184^{* *}$ & $-1.784^{* * *}$ \\
& $(0.124)$ & $(1.159)$ & $(0.136)$ & $(0.601)$ & $(0.109)$ & $(0.448)$ & $(0.071)$ & $(0.409)$ \\
\hline Observations & 268 & 268 & 282 & 282 & 286 & 286 & 276 & 276 \\
R-squared & 0.924 & 0.902 & 0.895 & 0.827 & 0.891 & 0.742 & 0.879 & 0.489 \\
\hline \hline
\end{tabular}

Notes: Coefficients reported are from regressions of first-differences in the log of the house price index on the inflow of immigrants as a share of the initial population. Local authorities are divided into four groups according to the quartiles of the distribution of the share of immigrants with lower education (below GCSE). Separate regressions are estimated for each of these four groups of local authorities. Robust standard errors clustered by local authority in parentheses. Regressions include year and local authority fixed effects and the change in the employment to population ratio.

$\begin{array}{ll}* * * & \text { significant at } 1 \% \\ * * & \text { significant at } 5 \% \\ * & \text { significant at } 10 \%\end{array}$ 
Table 12. Immigrant inflows and annual log house price changes - broad regions, 1996-2009

$\Delta \log$ house price index

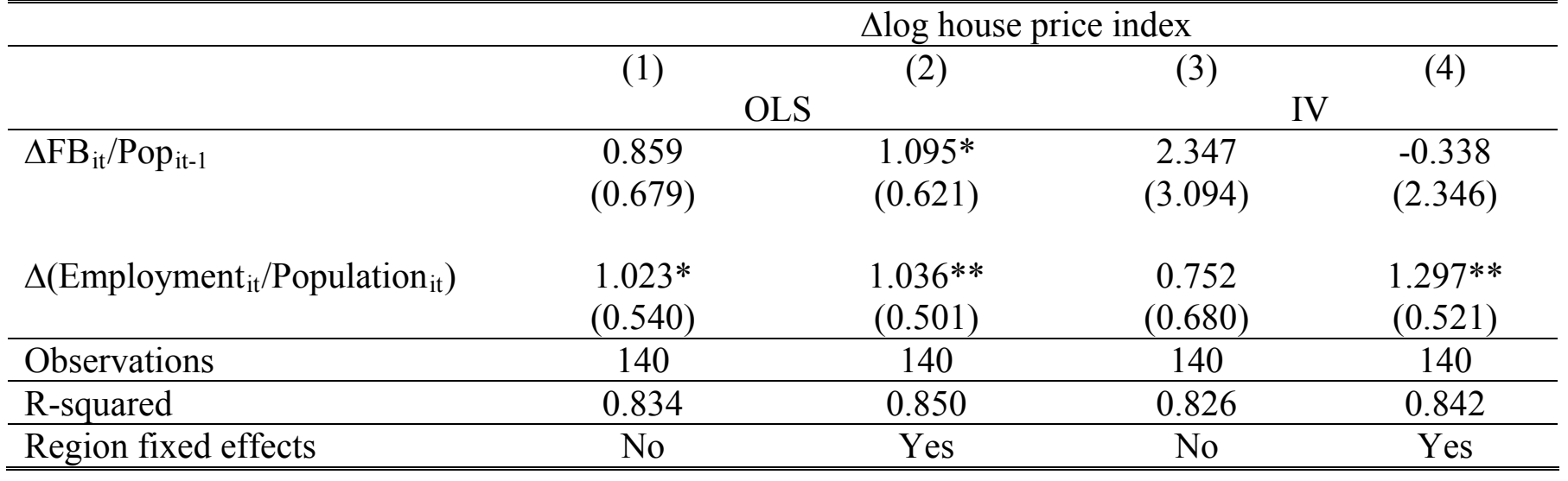

Notes: Robust standard errors. $\Delta$ indicates first difference. Regressions include year fixed effects.

*** $\quad$ significant at $1 \%$

** $\quad$ significant at $5 \%$

* $\quad$ significant at $10 \%$

Table 13. First stage regression - broad regions

\begin{tabular}{lc}
\hline \hline & $\Delta \mathrm{FB}_{\mathrm{it}} / \mathrm{Pop}_{\mathrm{it}-1}$ \\
\hline instrument & $0.709^{* *}$ \\
& $(0.326)$ \\
\hline Observations & 140 \\
\hline \hline
\end{tabular}

Notes: Robust standard errors in parentheses. $\Delta$ indicates first difference. Regressions include year and region fixed effects and the change in the employment to population ratio. The instrument is the change in the predicted foreign-born population relative to the total initial population. It uses the settlement pattern of immigrants in the 1991 Census to predict the number of foreign-born in each region in the current period.

$\begin{array}{ll}* * * & \text { significant at } 1 \% \\ * * & \text { significant at } 5 \% \\ * & \text { significant at } 10 \%\end{array}$ 